\title{
ANNOUNCEMENT
}

\section{The 53rd Annual Meeting of the Japan Wood Research Society in Fukuoka}

Date: March 22-24, 2003

Venue: Kyushu Sangyo University, Fukuoka, Japan

The Japan Wood Research Society (JWRS) takes great pleasure in inviting all members of our society with an interest in the science and technology of wood to attend the 53rd Annual Meeting of the JWRS that will be held from March 22 to 24, 2003, at Kyushu Sangyo University, Fukuoka, Japan.

Society members may make oral and poster presentations during the meeting. Titles and brief abstracts must be received no later than January 8, 2003. For more information please refer to the following web site.

http://brc.wood.agr.kyushu-u.ac.jp/wood2003/

Organizing committee: Prof. Hiroo Tanaka (Chairman)

Department of Forest and Forest Products Sciences

Faculty of Agriculture

Kyushu University

e-mail: toiawase@agr.kyushu-u.ac.jp

\section{Mokuzai Gakkaishi (Journal of the Japan Wood Research Society)}

Mokuzai Gakkaishi is another official journal of the Japan Wood Research Society. This journal publishes original articles, notes, review articles, and announcements from the Society in Japanese but with English abstracts, tables, and figure captions for original reports. Contents of the latest issue of Mokuzai Gakkaishi are as follows:

Volume 48 Number $5 \quad 2002$

Review article

\section{S. Fujikawa}

Structural characteristics of xylem parenchyma cell walls of trees in relation to the freezing adaptation

\section{Original articles}

M. Fujita, Y. Midorikawa, Y. Ishida

Experimental conditions for quantitative image analysis of wood cell structure I: Evaluation of various errors in ordinary accumulation image analysis

Y. Ogata, T. Kadokawa, M. Fujita

Experimenal conditions for quantitative image analysis of wood cell structure II: Non-microscopic image sampling over very wide areas using a film scanner

E. Obataya, T. Higashihara, B. Tomita

Hygroscopicity of heat-treated wood III: Effect of steaming on the hygroscopicity of wood

Y. Matsuoka, J. Gotou, S. Fujiwara, Y. Kanagawa Penetration of paraffin into sugi structural timber during high-temperature liquid drying
H. Yamauchi, I. Miura, Y. Okazaki, S. Kawai, H. Sasaki

Manufacture of cylindrical LVL by spiral-winding method III: Relationships between tensile strength, veneer grain angle, and butt joint interval in LVL

M. Kishino, T. Nakano

Adhesion and coating properties of Chinese and Japanese Shinanoki (Tilia spp.)

S. Nagahama, H. Fujii, T. Sonoda, M. Sasaki

Terpenoids of the wood oil of Sugi (Cryptomeria japonica) VIII: Components of KenKunisaki-5 and five other elite clones

Note

Y. Kitagawa, T. Awano, K. Takabe, M. Fujita Specimen preparation for observing woody plant cells under the high resolution scanning electron microscope 


\section{The Japan Wood Research Society}

The Japan Wood Research Society was founded in 1955 and has about 2,400 members including more than 150 overseas members. Membership is open to anyone interested in forest products science and wood technology. For more information, please contact:

The Japan Wood Research Society, 1-1-17 Mukogaoka, Bunkyo-ku, Tokyo 113-0023, Japan

Telephone: +81-3-3816-0396, Fax: +81-3-3818-6568, E-mail: office@jwrs.org

URL: http://www.jwrs.org/

\section{Membership Application Form}

The Japan Wood Research Society

Name:
First
Last

Title:

Organization/Company/School:

Mailing Address: $\square$ Home $\square$ Business Street/P.O.

City State/Country Zip/Postal Code

Telephone: Fax:

E-mail Address:

Please check one:

Institutional Membership: $¥ 16,000$ in Japan / $¥ 18,000$ in all other countries.

Individual Membership: $¥ 10,000$ in Japan / $¥ 12,000$ in all other countries.

Student Membership: $¥ 7,000$ in Japan / $¥ 9,000$ in all other countries for full-time students only.

(All memberships include subscriptions to the Mokuzai Gakkaishi and the Journal of Wood Science.)

$\square$ Please find my check enciosed. (Make checks payable to the Japan Wood Research Society.)

$\square$ Please bill my: $\square$ VISA $\square$ Master Card

Card Acct. No.: Expiration Date:

Cardholder Name:

Signature: Date:

Send application form and payment by mail or fax to the Society's office. 